\title{
An activity-based model for estimating manpower cost of university education
}

\author{
${ }^{1}$ Oluleye, A. E. ${ }^{2}$ Amaghionyeodiwe C.A. and ${ }^{3}$ Anyaeche ${ }^{\star}$, C.O. \\ Department of Industrial and Production Engineering, University of Ibadan, Ibadan, Nigeria.
}

\begin{abstract}
Higher education is regarded as a public good, recognized as forming vital social functions and disseminating knowledge. Of recent, the shortage of funds, the introduction of neo-liberal policies and globalization have contributed to rapid growth and a shift in emphasis to privatization of education. This appears a global trend. The cut in funding University coupled with increasing quest for university education have continued to stretch the dexterity of University administrators on quality. The university system has in recent years not been able to admit as it would have. In this work, an activity-based model was developed and used to estimate the manpower cost per student in a department offering engineering courses in a Nigerian University. This model was applied in 2003 and 2007. In 2003, 300 level courses had the highest cost. It was found that 200 and 300 levels attracted about $64 \%$ of the total cost. However, in 2007, 100 level courses recorded the highest costs, raising questions about the cost of borrowing courses from the servicing Faculty of Science, which provides about $80 \%$ of the borrowed courses. This work developed an activity based model for evaluating university manpower requirements and presented graduated stepped format for bridging gaps.
\end{abstract}

Keywords: University Funding; Education; Manpower Cost; Activity-Based.

\section{INTRODUCTION}

Conventionally, higher education is regarded as a public good, benefiting not only the individuals but also the whole society. Higher education institutions are recognized as important social institutions, performing vital social functions, that are widely acknowledged as noble and core for the very sustenance of societies, besides creating and disseminating knowledge. But of late, the chronic shortage of public funds for higher education, the widespread introduction of neo-liberal economic policies and globalization in every country and in every sector have contributed to the rapid growth in privatization of education (Tilak, 2008). This appears a global trend. In India too, the introduction of neoliberal policies in the early 1990s has resulted in a significant shift in public approach to education: the public good character is being forgotten, and the profit-seeking private sector is gaining strength. These pose serious problems relating to access, quality, and equity in education, resulting in dangerous cracks in the edifice of higher education (Budhwar and Boyne, 2004; Anyaeche, 2007; Tilak, 2008).
Recently in Nigeria, university funding remained more or less on the same nominal level. There had been a severe cut in funding the universities despite the increase in the intake. In order to meet the needs of the increasing number of students entering the university, development of new teaching methods require urgent attention. Part of the response to this was the growth in the number of universities from 71 in 2003 to 91 in 2007 with private universities $(0 \%$ in 1998) constituting about 34\%, (Anyaeche, 2007). Measures have to be taken to avoid a drop in the quality and quantity of education or unduly emphasizing the profit motive of the private enterprise. It is therefore pertinent that the available resources be used in an efficient and effective manner, and this calls for developing an effective costing methodology which enables resources to be allocated effectively and utilized efficiently.

This paper attempts to develop an activity-based model for estimating the labour (manpower) cost of university education. Labour remains not just the most critical item or resource for productivity, but the only resource conscious of its contribution to system's performance (Anyaeche, 2007). It is therefore necessary to closely assess its utilization and cost. The activities identified are formal teaching, 
practical, students counseling and assessment, research, community services, general administration and formal examination. The manpower cost associated with industrial and production-engineering education was estimated using the developed model. The estimated cost was then compared with that based on the National University Commission (NUC) norm and gap bridging analysis conducted in 2003. Furthermore, a four-year period review was carried out in 2007.

Previous work: Universities in Nigeria are currently experiencing some difficulties as there is less money to spend on teaching, research and community services. Universities complain of underfunding while the government accuses the universities of inefficient utilization of available resources (Babalola, 2001).

For adequate planning and managing of educational system, this study estimates the unit cost per student in a university with emphases on engineering education.

Babalola, et al (1996) computed the unit cost of University education by discipline as the addition of average joint cost and the average variable cost, that is,

$\mathrm{UC}_{\mathrm{i}}=\mathrm{AJC}+\mathrm{AVC}_{\mathrm{i}} \ldots$

where, $U C_{i}=$ unit cost in University $\mathrm{i}$

$\mathrm{AJC}=$ average joint cost

$A \vee C_{i}=$ average variable cost in University $i$

Babalola (2000) applied a quadratic curve estimation regression model to estimate the unit cost per student at a faculty in the University of Ibadan. The model is given thus:

$\mathrm{UC}_{\mathrm{i}}=\mathrm{b}_{0}+\mathrm{b}_{1} \mathrm{E}^{1}+\mathrm{b}_{2} \mathrm{E}^{2}$

where, $U C_{i}$ is the unit cost per student in faculty $i$

$b_{0}$ is the fixed cost

$b_{1}, b_{2}$ are partial regression coefficients.

$E^{1}, E^{2}$ are enrolments liable to errors.

However, this work uses a different approach by developing an activity based model for cost estimation. It examined the cost per student based on the different types of activities involved. It differs from those earlier listed, by the virtue of its uniqueness, degree of accuracy, effectiveness and flexibility. The model tracks the cost generating activities of university education. The model formulation is thus discussed in the next section.
Model development: The cost evaluation model was designed in relation to the various levels of learning, activities and courses available in a university system. The study considered courses from 100 through 500 levels. The activities identified are formal teaching, practical, research, formal examination, student counseling and assessment, general administration and community services. The courses include both those offered in the department and outside the department.

Assumptions and limitations : The following assumptions are made in this work

1. Academic counseling and continuous assessment of students play a significant role in effective learning.

2. More than one lecturer can handle a course.

3. Scheduled period for lecturer, practical and students' counseling and assessment are strictly adhered to.

4. A lecturer carries out his activities independent of other lecturers.

Notations and terminologies: The notations and terminologies adopted in this study are as follows:

$\mathrm{k}=$ Activities carried out in relation with courses

$\mathrm{t}=$ Activities carried out independent of courses

CS $_{\mathrm{ij}} \quad=$ Course $\mathrm{j}$ offered at level $\mathrm{i}$

$\mathrm{A}_{\mathrm{k}} \quad=$ Activity $\mathrm{k}$, where $\mathrm{k}=1,2 \ldots \ldots \ldots \mathrm{m}$

$A_{t} \quad=$ Activity $t$ where $t=1,2,-------, w$

$\mathrm{Y}_{\mathrm{jik}} \quad=$ The proportion of time spent on course $\mathrm{j}$ at level $\mathrm{i}$ in relation to activity $\mathrm{k}$

$\mathrm{L}_{\mathrm{s}} \quad=$ Identity describing lecturer ' $\mathrm{s}$ ' involved in the training of student

$Z_{\text {st }} \quad=$ The proportion of time lecturer ' $s$ ' spent carrying out activity $t$

$\mathrm{X}_{\mathrm{si}} \quad=$ Amount in naira lecturer ' $\mathrm{s}$ ' taken courses at level i receives

$\alpha_{\mathrm{ijk}}=$ Cost associated with course $\mathrm{j}$ at level $\mathrm{i}$ in relation to activity $\mathrm{k}$

$\eta_{\text {st }}=$ Cost associated with lecturer ' $s$ ' with respect to activity $t$

MCF $_{\mathrm{i}}=$ Manpower cost function of level $\mathrm{i}$ 
$\mathrm{MC}_{\mathrm{i}} \quad=$ Manpower cost per student at level $\mathrm{i}$

$\lambda_{\mathrm{i}} \quad=$ Number of student at level $\mathrm{i}$

Formulation: The manpower cost is computed by considering the percentage (proportion) of time spent on each of the courses with respect to individual activity. This is multiplied with the salary and the lump sum computed. To obtain the information on the time spent, a questionnaire was administered and also developed the activity-course matrix, shown in figure 1, with element $Y_{j \mathrm{jk}}$ obtained. The element $Y_{j \mathrm{jk}}$ is a number representing the proportion of time spent on course $\mathrm{j}$ at level $\mathrm{i}$ in relation to activity $\mathrm{k}$, where $\mathrm{j}=1$, $2, \ldots \ldots n$.
Since that some activities are carried out independent of courses. We therefore develop a matrix specifying the proportion of time spent carrying out these activities per lecturer. The activity-lecturer matrix shown in Table 2 has $Z_{s t}$ as element. $Z_{s t}$ is a number representing the proportion of time lecturer' spent carrying out activity $t$, where $s=1,2$, ................. $\mathrm{h}$

Also, a salary matrix describing the salaries of the individual lecturers, with element $\mathrm{X}_{\mathrm{si}}$, was developed. This is shown in Table 3 , The element $X_{\text {si }}$ represents the amount lecturer ' $s$ ' who teaches at level $i$ receives.

Table 1: An activity-course matrix showing the proportion of time spent on courses with respect to individual activity level i

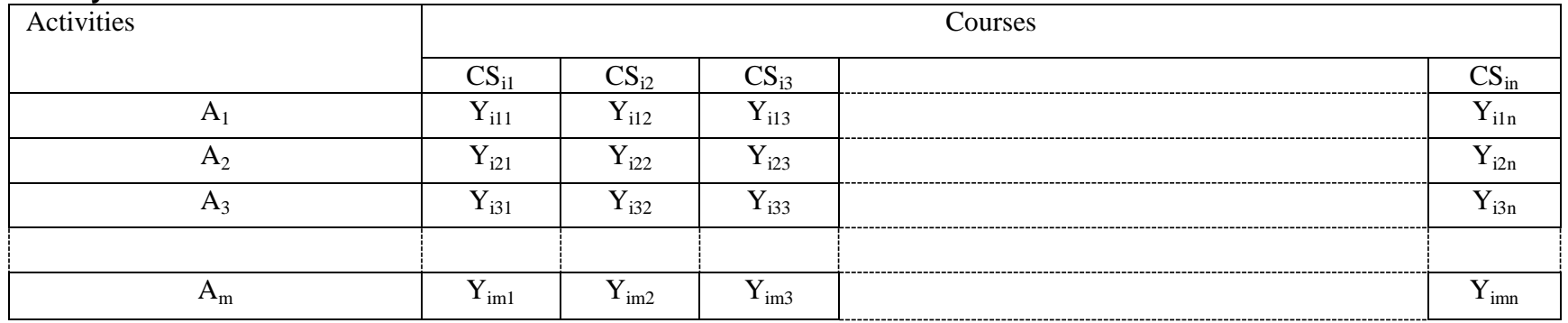

Table 2: The proportion of time spent on activities independent of courses.

\begin{tabular}{|c|c|c|c|c|}
\hline \multirow[t]{2}{*}{ Activities } & \multicolumn{4}{|c|}{ Lecturer } \\
\hline & $\mathrm{L}_{1}$ & $\mathrm{~L}_{2}$ & $\mathrm{~L}_{3}$ & $\mathrm{~L}_{\mathrm{h}}$ \\
\hline $\mathrm{A}_{1}$ & $Z_{11}$ & $Z_{12}$ & $Z_{13}$ & $\mathrm{Z}_{1 \mathrm{~h}}$ \\
\hline $\mathrm{A}_{2}$ & $\overline{Z_{21}}$ & $\mathrm{Z}_{22}$ & $\overline{Z_{23}}$ & $\mathrm{Z}_{2 \mathrm{~h}}$ \\
\hline $\mathrm{A}_{3}$ & $Z_{31}$ & $\mathrm{Z}_{32}$ & $Z_{33}$ & $Z_{3 h}$ \\
\hline $\mathrm{A}_{\mathrm{w}}$ & $Z_{\mathrm{w} 1}$ & $\mathrm{Z}_{\mathrm{w} 2}$ & $\mathrm{Z}_{\mathrm{w} 3}$ & $\mathrm{Z}_{\mathrm{wh}}$ \\
\hline
\end{tabular}

Table 3: A matrix showing the amount received by individual lecturer at various levels

\begin{tabular}{|c|c|c|c|c|c|c|}
\hline \multirow[b]{2}{*}{ Level } & \multicolumn{6}{|c|}{ Lecturer } \\
\hline & $\mathrm{L}_{1}$ & $\mathrm{~L}_{2}$ & $\mathrm{~L}_{3}$ & $\mathrm{~L}_{4}$ & $\mathrm{~L}_{5}$ & $L_{h}$ \\
\hline 1 & $X_{11}$ & $X_{12}$ & $\mathrm{X}_{13}$ & $X_{14}$ & $X_{15}$ & $X_{1 h}$ \\
\hline 2 & $X_{21}$ & $X_{22}$ & $X_{23}$ & $X_{24}$ & $\mathrm{X}_{25}$ & $X_{2 h}$ \\
\hline 3 & $X_{31}$ & $X_{32}$ & $X_{33}$ & $X_{34}$ & $X_{35}$ & $X_{3 h}$ \\
\hline 4 & $\mathrm{X}_{41}$ & $\mathrm{X}_{42}$ & $\mathrm{X}_{43}$ & $\mathrm{X}_{44}$ & $X_{45}$ & $\mathrm{X}_{4 \mathrm{~h}}$ \\
\hline 5 & $X_{51}$ & $X_{52}$ & $\mathrm{X}_{53}$ & $X_{54}$ & $X_{55}$ & $X_{5 h}$ \\
\hline
\end{tabular}

It has been noted that a lecturer can take courses in more than one level. Figures 1 and 2 are used with
Table 3 to develop the manpower cost matrix as well as the manpower cost function. The manpower cost 
is shown in Table 4. Matrix of figure 4 has element $\alpha_{i j k}$ representing the cost associated with course $j$ at level $\mathrm{i}$ in relation to activity $\mathrm{k}$. It is calculated as:

$$
\alpha_{\mathrm{ijk}}=Y_{\mathrm{ijk}} X_{\mathrm{si}} \quad \ldots 3
$$

The matrix of Table 5 has in it element $\eta$ st. This represents the cost associated with lecturer ' $s$ ' with Table 4: Matrix of costs associated with courses

\begin{tabular}{|c|c|c|c|c|c|}
\hline \multirow[b]{2}{*}{ Activities } & \multicolumn{4}{|c|}{ Courses } & Row Total \\
\hline & $\mathrm{CS}_{i 1}$ & $\mathrm{CS}_{\mathrm{i} 2}$ & $\mathrm{CS}_{i 3}$ & $\mathrm{CS}_{\text {in }}$ & \multirow{5}{*}{$\sum_{j=1}^{n} \alpha_{i j k}$} \\
\hline $\mathrm{A}_{1}$ & $\alpha_{i 11}$ & $\alpha_{i 12}$ & $\alpha_{i 13}$ & $\alpha_{i 1 n}$ & \\
\hline$A_{2}$ & $\alpha_{\mathrm{i} 21}$ & $\alpha_{\mathrm{i} 22}$ & $\alpha_{i 23}$ & $\alpha_{\mathrm{i} 2 n}$ & \\
\hline$A_{3}$ & $\alpha_{i 31}$ & $\alpha_{\mathrm{i} 32}$ & $\alpha_{i 33}$ & $\alpha_{i 3 n}$ & \\
\hline$A_{m}$ & $\alpha_{\mathrm{im} 1}$ & $\alpha_{i m 2}$ & $\alpha_{\text {im3 }}$ & $\alpha_{\text {imn }}$ & \\
\hline
\end{tabular}

Table 5: Matrix of costs associated with staff.

\begin{tabular}{|c|c|c|c|c|c|}
\hline & Lecturer & Row Total & & & \\
\hline Activities & $\mathrm{L}_{1}$ & $\mathrm{~L}_{2}$ & $\mathrm{~L}_{3}$ & $L_{h}$ & \multirow{5}{*}{$\begin{array}{l}r \\
\sum_{s=1}^{r} \eta_{w h}\end{array}$} \\
\hline $\mathrm{A}_{1}$ & $\eta_{11}$ & $\eta_{12}$ & $\eta_{13}$ & $\eta_{1 \mathrm{~h}}$ & \\
\hline$A_{2}$ & $\eta_{21}$ & $\eta_{22}$ & $\eta_{23}$ & $\eta_{2 h}$ & \\
\hline$A_{3}$ & $\eta_{31}$ & $\eta_{32}$ & $\eta_{33}$ & $\eta_{3 h}$ & \\
\hline$A_{w}$ & $\eta_{w 1}$ & $\eta_{\mathrm{w} 2}$ & $\eta_{w 2}$ & $\eta_{\mathrm{wh}}$ & \\
\hline
\end{tabular}

The manpower cost function $\left(\mathrm{MCF}_{\mathrm{i}}\right)$ for a particular level $\mathrm{i}$ is thus computed as:

$$
M C F_{i}=\sum_{k=1}^{m} \sum_{j=i}^{n} \alpha_{i j k}++\sum_{t=1}^{w} \sum_{s=1}^{r} \eta_{s t} \quad 5
$$

hence, the manpower cost per student at level $\mathrm{i}\left(\mathrm{MC}_{\mathrm{i}}\right)$ is thus,

$$
\mathrm{MC}_{\mathrm{i}}=\mathrm{MCF}_{\mathrm{i}} / \lambda_{\mathrm{I}} \quad 6
$$

where, $\lambda_{i}=$ number of students at level $i$

Application of the model: Faculty of Technology was used in this study as the sample population from which Industrial and Production Engineering Education was then selected. This was based on accessibility. Experience shows that financial data are treated confidentially in Nigeria. It is therefore important to consider easy accessibility to the source of data. This makes the data collection process costeffective. respect to activity $t$. Thus, the value of $\eta_{s t}$ is computed as :

$$
\eta_{\mathrm{st}}=\mathrm{Z}_{\mathrm{st}} \times \mathrm{X}_{\mathrm{si}} \quad \ldots
$$


independent of courses are presented in Table 2 (100 level only).

Table 7 reveals that more time is spent on personal research than general administration and community services. This indicates that personal research is the major activity carried out outside the classroom work.
Table 8 gives the lecturers' weekly wages, while the manpower cost associated with activities that are linked with courses for 200 level are shown in Table 9 while that associated with activities carried out independent of courses are presented in Table 10, which is split into $10 \mathrm{a}, 10 \mathrm{~b}$ and $10 \mathrm{c}$ to enhance the presentation.

Table $6 a$ : The proportion of time spent on 100 level courses/activities per week.

\begin{tabular}{|l|l|l|l|l|l|l|l|l|l|}
\hline & & \multicolumn{9}{|c|}{ COURSE CODE } \\
\cline { 3 - 10 } S/N & ACTIVITIES & TME 111 & $\begin{array}{l}\text { TME } \\
121\end{array}$ & $\begin{array}{l}\text { MAT } \\
101\end{array}$ & MAT 111 & $\begin{array}{l}\text { MAT } \\
121\end{array}$ & $\begin{array}{l}\text { MAT } \\
141\end{array}$ & $\begin{array}{l}\text { CHE } \\
127\end{array}$ & CHE 157 \\
\hline & Formal Teaching & 0.0714 & 0.0535 & 0.0555 & 0.0476 & 0.0476 & 0.0655 & 0.0476 & 0.0696 \\
\hline 2 & Practical & - & 0.0179 & - & - & - & - & - & - \\
\hline 3 & $\begin{array}{l}\text { Student } \\
\text { Assessment and } \\
\text { Consultation }\end{array}$ & 0.0476 & 0.0446 & 0.0298 & 0.0446 & 0.0595 & 0.0441 & 0.0595 & 0.0446 \\
\hline 4 & $\begin{array}{l}\text { Formal } \\
\text { Examination }\end{array}$ & 0.1667 & 0.1488 & 0.1488 & 0.2083 & 0.1935 & 0.2010 & 0.1905 & 0.2083 \\
\hline
\end{tabular}

(Source: Computed from field survey)

Table $6 \mathrm{~b}$ : The proportion of time spent on 100 level courses/activities per week.

\begin{tabular}{|l|l|l|l|l|l|l|l|l|l|}
\hline & & \multicolumn{9}{|c|}{ COURSE CODE } \\
\cline { 3 - 10 } S/N & ACTIVITIES & $\begin{array}{l}\text { CHE } \\
177\end{array}$ & $\begin{array}{l}\text { CHE } \\
195\end{array}$ & $\begin{array}{l}\text { PHY } \\
112\end{array}$ & $\begin{array}{l}\text { PHY } \\
113\end{array}$ & $\begin{array}{l}\text { PHY } \\
114\end{array}$ & PHY 115 & PHY & STA 111 \\
\hline 1 & Formal Teaching & 0.0595 & 0.07440 & 0.0476 & 0.0446 & 0.0476 & 0.0417 & 0.0655 & 0.0417 \\
\hline 2 & Practical & - & 0.0446 & - & - & - & - & 0.0445 & - \\
\hline 3 & $\begin{array}{l}\text { Students' } \\
\text { Assessment and } \\
\text { Consultation }\end{array}$ & 0.0446 & 0.0598 & 0.0595 & 0.0595 & 0.0446 & 0.0595 & 0.0595 & 0.0744 \\
\hline 4 & $\begin{array}{l}\text { Formal } \\
\text { Examination }\end{array}$ & 0.2143 & 0.0298 & 0.2083 & 0.2143 & 0.2083 & 0.2143 & 0.0298 & 0.0417 \\
\hline
\end{tabular}

(Source: Computed from field survey)

Table 7: Proportion of time spent by lecturers on activities independent of 200 level courses per week

\begin{tabular}{|l|l|l|l|l|l|l|l|l|l|l|l|l|l|}
\hline & & \multicolumn{10}{|c|}{ S/N } & ACTIVITIES & \multicolumn{10}{|c|}{ LECTURER'S CODE } \\
\cline { 2 - 15 } & $\begin{array}{l}\text { Personal } \\
\text { research }\end{array}$ & 0.45 & 0.45 & 0.50 & 0.40 & 0.50 & 0.40 & 0.40 & 0.50 & 0.65 & 0.4 & 0.45 \\
\hline 2 & $\begin{array}{l}\text { General } \\
\text { administration }\end{array}$ & 0.30 & - & 0.10 & 0.10 & - & 0.10 & 0.20 & - & - & 0.10 & - \\
\hline 3 & $\begin{array}{l}\text { Community } \\
\text { service }\end{array}$ & 0.10 & 0.10 & 0.20 & 0.10 & - & 0.10 & - & - & - & - & - \\
\hline
\end{tabular}

Table 7. Continued

\begin{tabular}{|l|l|l|l|l|l|l|l|l|l|l|l|}
\hline 1 & Personal research & 0.40 & 0.40 & 0.55 & 0.40 & 0.40 & 0.40 & 0.45 & 0.40 & 0.20 & 0.30 \\
\hline 2 & General administration & - & - & - & - & 0.20 & 0.10 & - & - & - & - \\
\hline 3 & Community service & - & - & - & - & - & 0.10 & - & 0.10 & - & - \\
\hline
\end{tabular}

(Source: Computed from field survey) 
Am. J. Sci. Ind. Res., 2012, 3(6): 345-357

Table 8: Lecturer's weekly wages.

\begin{tabular}{|c|c|c|c|c|c|c|c|c|c|c|}
\hline \multirow{3}{*}{$\begin{array}{l}\text { LEVEL } \\
100\end{array}$} & \multicolumn{10}{|c|}{ LECTURER'S CODE } \\
\hline & \multicolumn{10}{|c|}{ AMOUNT (A) PER WEEK } \\
\hline & L001 & L002 & L003 & L004 & L005 & L006 & L007 & L008 & L009 & L010 \\
\hline \multirow[t]{2}{*}{200} & L024 & L036 & L037 & L038 & L039 & L040 & L041 & L042 & L043 & L044 \\
\hline & 11936.44 & 5637.79 & 3897.83 & 5637.79 & 5637.79 & 5637.79 & 5637.79 & 5065.71 & 6435.39 & 7630.48 \\
\hline 300 & L025 & L026 & L027 & L029 & L032 & L033 & L040 & L004 & L005 & L001 \\
\hline \multirow[t]{2}{*}{400} & L029 & L030 & L031 & L033 & L034 & L040 & L041 & L063 & L064 & \\
\hline & 5637.79 & 8108.52 & 5637.79 & 5037.89 & 5637.89 & 5637.79 & 5637.79 & 3899.83 & 6435.39 & \\
\hline \multirow[t]{2}{*}{500} & L027 & L028 & L029 & L030 & L031 & L032 & L034 & L065 & & \\
\hline & 8108.52 & 8108.52 & 5637.79 & 8108.52 & 5637.89 & 5637.79 & 5637.89 & 3899.83 & & \\
\hline
\end{tabular}

TABLE 8: LECTURER'S WEEKLY WAGES CONTINUED

\begin{tabular}{|c|c|c|c|c|c|c|c|c|c|c|c|}
\hline LEVEL & \multicolumn{11}{|c|}{ LECTURER'S CODE / AMOUNT (A) PER WEEK } \\
\hline 100 & L011 & L012 & L013 & L013 & L014 & L015 & L016 & L017 & L018 & L019 & L023 \\
\hline & 5885.63 & 11935.44 & 10327.65 & 10894.17 & 12986.23 & 12986.23 & 4866.17 & 8108.52 & 7767.37 & 4866.17 & \\
\hline 200 & L045 & L046 & L047 & L048 & L049 & L050 & L051 & L052 & L001 & L004 & \\
\hline & 5065.71 & 5637.79 & 5637.79 & 4866.17 & 8108.52 & 5065.21 & 4866.17 & 4866.17 & & & \\
\hline 300 & L037 & L002 & L039 & L053 & L054 & L055 & L056 & L057 & L058 & L059 & L066 \\
\hline & 3899.83 & 5637.99 & 5637.99 & 8108.52 & 11589.02 & 13933.89 & 8108.52 & 5065.71 & 5637.79 & 8399.83 & 11241.60 \\
\hline 400 & & & & & & & & & & & \\
\hline & & & & & & & & & & & \\
\hline 500 & & & & & & & & & & & \\
\hline
\end{tabular}

Table 9: Matrix showing the manpower cost associated with 300 level courses with respect to activities per week

\begin{tabular}{|c|c|c|c|c|c|c|c|c|c|c|c|}
\hline & & \multicolumn{10}{|c|}{ COURSE CODE /AMOUNT ( $\#$ ) PER YEAR } \\
\hline $\mathrm{S} / \mathrm{N}$ & Activities & $\begin{array}{l}\text { TIE } \\
311\end{array}$ & TIE 312 & TIE 313 & TIE 314 & TIE 321 & TIE 322 & $\begin{array}{l}\text { TEL } \\
315\end{array}$ & $\begin{array}{l}\text { TEL } \\
323\end{array}$ & $\begin{array}{c}\text { ECO } \\
311\end{array}$ & $\begin{array}{l}\text { STA } \\
353\end{array}$ \\
\hline 1 & $\begin{array}{l}\text { Formal } \\
\text { Teaching }\end{array}$ & 3626.2 & 3626.23 & 2821.2 & 4057.5 & 2415.23 & 2821.2 & 1951.5 & 2415.2 & 1740.1 & 7230.8 \\
\hline 2 & Practical & - & - & - & 2899.61 & - & 2415.2 & - & - & - & - \\
\hline 3 & $\begin{array}{l}\text { Assessment } \\
\text { and } \\
\text { Consultation }\end{array}$ & 2016.1 & 1610.15 & 3017.4 & 3473.69 & 1610.15 & 1610.2 & 1670.7 & 1610.2 & 1740.1 & 4815.9 \\
\hline 4 & $\begin{array}{l}\text { Formal } \\
\text { Examination }\end{array}$ & 906.56 & 906.56 & 4697.4 & 4707 & 2012.69 & 4296 & 1253 & 2012.7 & 2824.8 & 6525.8 \\
\hline
\end{tabular}


Am. J. Sci. Ind. Res., 2012, 3(6): 345-357

Table 9: Continued

\begin{tabular}{|c|c|c|c|c|c|c|c|c|c|c|c|}
\hline & & \multicolumn{10}{|c|}{ COURSE CODE } \\
\hline & & \multicolumn{10}{|c|}{ AMOUNT (A) PER YEAR } \\
\hline $\begin{array}{l}\mathrm{S} / \\
\mathrm{N}\end{array}$ & ACTIVITIES & $\begin{array}{l}\text { TPE } \\
316\end{array}$ & $\begin{array}{l}\text { TME } \\
312\end{array}$ & $\begin{array}{l}\text { TME } \\
313\end{array}$ & $\begin{array}{l}\text { TME } \\
314\end{array}$ & TME 315 & $\begin{array}{l}\text { TME } \\
321\end{array}$ & $\begin{array}{l}\text { TME } \\
322\end{array}$ & $\begin{array}{l}\text { TME } \\
323\end{array}$ & $\begin{array}{l}\text { TME } \\
324\end{array}$ & TOTAL \\
\hline 1 & $\begin{array}{c}\text { Formal } \\
\text { Teaching }\end{array}$ & 1811.5 & 14153.6 & 8274.6 & 2415.23 & 6377.34 & 6373.3 & 4431.3 & 3626.2 & 1394.6 & 81563 \\
\hline 2 & Practical & - & 4735.49 & 2489.3 & 1610.15 & - & - & - & 1610.2 & - & 15760 \\
\hline 3 & $\begin{array}{l}\text { Assessment } \\
\text { and } \\
\text { Consultation }\end{array}$ & 1446.8 & 6296.34 & 4144.2 & 2415.23 & 7639.97 & 4339.7 & 3017.4 & 1610.2 & 1670.7 & 57365 \\
\hline 4 & $\begin{array}{c}\text { Formal } \\
\text { Examination }\end{array}$ & 1627.6 & 14173.4 & 3723.6 & 3222 & 6366.64 & 5213 & 3624.5 & 1811.4 & 1392.2 & 71297 \\
\hline
\end{tabular}

Table 10a: Manpower cost of lecturers for activities at 300 level.

\begin{tabular}{|l|l|l|l|l|l|l|l|l|l|l|}
\hline \multirow{2}{*}{ S/N } & \multirow{2}{*}{} & \multicolumn{7}{|c|}{ LECTURER'S CODE } \\
\cline { 3 - 10 } & ACTIVITIES & L001 & L002 & L004 & L005 & L026 & L027 & L029 & L032 \\
\hline 1 & $\begin{array}{l}\text { Personal } \\
\text { research }\end{array}$ & 16865 & 117266.24 & 69102.38 & 113771.78 & 168657.22 & 168657.22 & 87947.50 & 131924.29 \\
\hline 2 & $\begin{array}{l}\text { General } \\
\text { administration }\end{array}$ & - & 14658.28 & - & - & - & 42164.30 & 58633.02 & 29316.51 \\
\hline 3 & $\begin{array}{l}\text { Community } \\
\text { service }\end{array}$ & 42164.2 & 29316.56 & - & - & 84528.61 & 84328.61 & 29316.51 & 87949.52 \\
\hline
\end{tabular}

Table 10b: Manpower cost for lecturers for activities at 300 level.

\begin{tabular}{|c|c|c|c|c|c|c|c|c|c|}
\hline \multirow[b]{3}{*}{$\mathrm{S} / \mathrm{N}$} & \multirow[b]{3}{*}{ ACTIVITIES } & \multicolumn{8}{|c|}{ LECTURER'S CODE } \\
\hline & & \multicolumn{8}{|c|}{ AMOUNT (N) PER YEAR } \\
\hline & & L033 & L037 & L039 & L040 & L066 & L056 & L057 & L058 \\
\hline 1 & $\begin{array}{l}\text { Personal } \\
\text { research }\end{array}$ & 87949.52 & 101395.58 & 146582.54 & 2255.29 & 478211.10 & 168657.22 & 52683.38 & 131924.29 \\
\hline 2 & $\begin{array}{l}\text { General } \\
\text { administration }\end{array}$ & 29316.51 & 20279.12 & - & 29316.51 & 72456.23 & - & 105366.77 & 58633.02 \\
\hline 3 & $\begin{array}{l}\text { Community } \\
\text { service }\end{array}$ & 58633.02 & 40558.23 & - & 29316.51 & 72456.23 & - & 79025.08 & - \\
\hline
\end{tabular}

Table 10c continued

\begin{tabular}{|c|c|c|c|c|c|c|c|c|c|}
\hline \multirow[b]{3}{*}{$\mathrm{S} / \mathrm{N}$} & \multirow[b]{3}{*}{ ACTIVITIES } & \multicolumn{8}{|c|}{ LECTURER'S CODE } \\
\hline & & \multicolumn{8}{|c|}{ AMOUNT (A) PER YEAR } \\
\hline & & L053 & L054 & L039 & L060 & L061 & L062 & L066 & TOTAL \\
\hline 1 & Personal research & 168657.22 & 271183.07 & 40558.23 & 117265.82 & 161240.51 & 101216.34 & 321508.76 & 3225483.5 \\
\hline 2 & $\begin{array}{l}\text { General } \\
\text { administration }\end{array}$ & 42164.30 & 60262.90 & - & 58682.91 & - & - & - & 621199.32 \\
\hline 3 & Community service & 84328.61 & - & 101395.58 & 29316.46 & 29316.46 & - & - & 411066.71 \\
\hline
\end{tabular}




\section{RESULTS AND DISCUSSION}

Table 11: Summary of the average cost and proportion at various levels

Table 11: Total Cost in 2003

\begin{tabular}{|c|c|}
\hline Level & Percentage \\
\hline 100.00 & 7.16 \\
\hline 200.00 & 26.37 \\
\hline 300.00 & 36.98 \\
\hline 400.00 & 13.53 \\
\hline 500.00 & 15.96 \\
\hline Total & 100.00 \\
\hline
\end{tabular}

\section{Results}

In 2003, the total cost per level is higher at 300 level compare with other levels. From figures 1 and 2, there is an increase of N2329704.69 from 100 level to 200 level, a rise of about $270 \%$. While there is about $41 \%$ increase from 200 level to 300 level, a fall of about $64 \%$ is experience from 300 level to 400 level. There is an increase of N294153.14, a rise of about $18 \%$ from 400 level to 500 level. These increases and decreases may be due to the number of courses offered, the number of lecturers as well
The summary of the total costs and percentage contributions for 2003 and 2007 are shown in Tables 11 and 12 respectively.

Table 12: Total Cost in 2007

\begin{tabular}{|c|r|}
\hline \multicolumn{1}{|l|}{ Level } & Percentage \\
\hline 100.00 & 38.49 \\
\hline 200.00 & 15.48 \\
\hline 300.00 & 26.93 \\
\hline 400.00 & 8.67 \\
\hline 500.00 & 10.42 \\
\hline Total & 100.00 \\
\hline
\end{tabular}

as the grade level of the lecturers involved in the teaching at each level.

From survey, more courses are offered in 300 level than other levels. Figure 1 reveals that the cost per student is more in 200 level compare with other levels while the least cost is attributed to 100 level. It also shows the trend in the cost per student from 100 level through 500 level. Breakdown of the cost (in percent) at various levels is shown in figure 6 with 200 level and 300 level attracting $63.35 \%$ of the total cost while 100 level attracts $7.16 \%$.

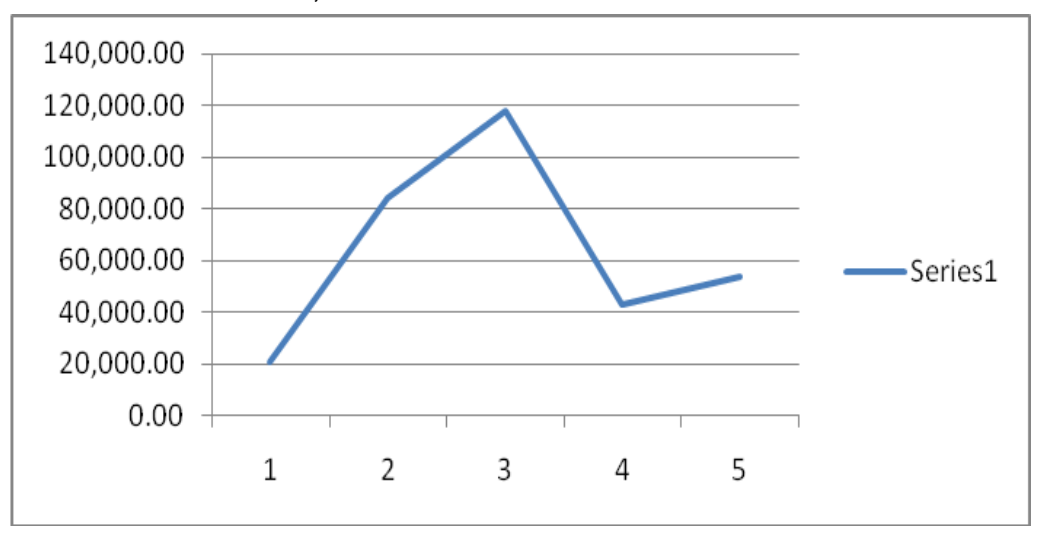

Fig 1: Cost per student in 2003.

Fig 1 gives the trend in the cost per student in 2003. Observe that 300 level cost/student was the highest in 2003. There was a considerable drop in 400 level. A possible cause is that 400 level students usually 
are out of the campus on industrial attachment (IT) during the second semester. The cost implications for the IT are not readily available, however, this could, be pursued in further work.

\section{Results}

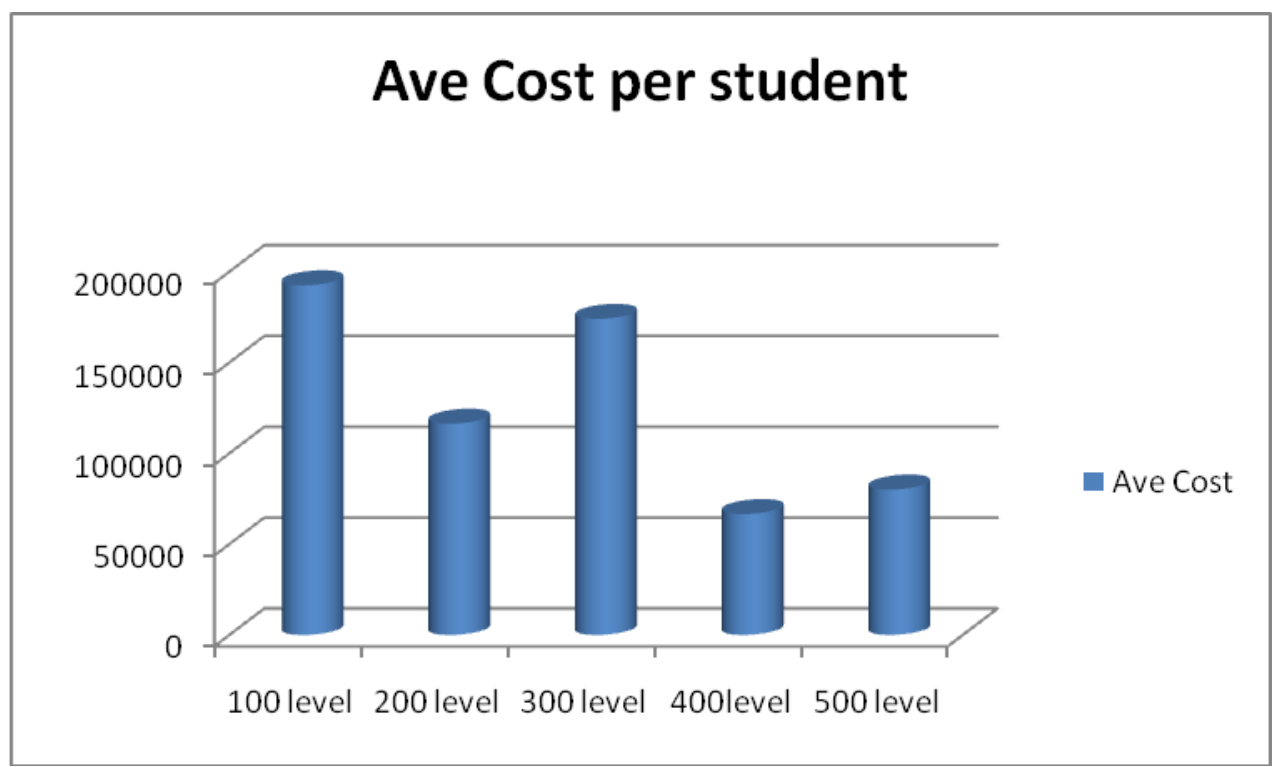

Fig. 2: Cost per student in 2007

In fig. 2, the cost/student in 2007 was again displayed. The trend shows that 100 level cost/student was the highest. An examination shows that these are service courses and had been reviewed by the servicing faculty. The implication is that the cost of borrowing had gone very high and should be closely monitored. It may be the policy of the University that since these courses are available in the servicing Faculty, they need not be replicated elsewhere. However, the department and indeed the Faculty of Technology could make a case for the reduction of these costs or a review in the light of these findings. 
Am. J. Sci. Ind. Res., 2012, 3(6): 345-357

Total cost per level

\section{Total Cost per level}
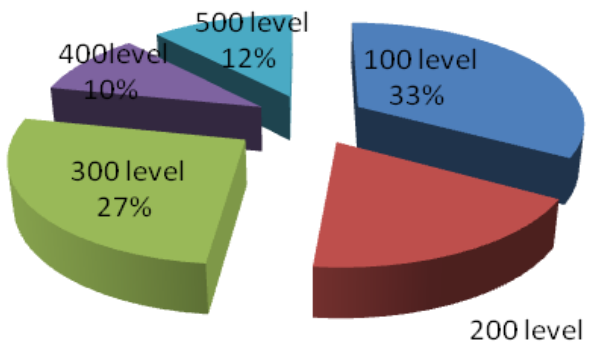

Fig. 3: Total cost per level

\section{Total average pay in 2007}

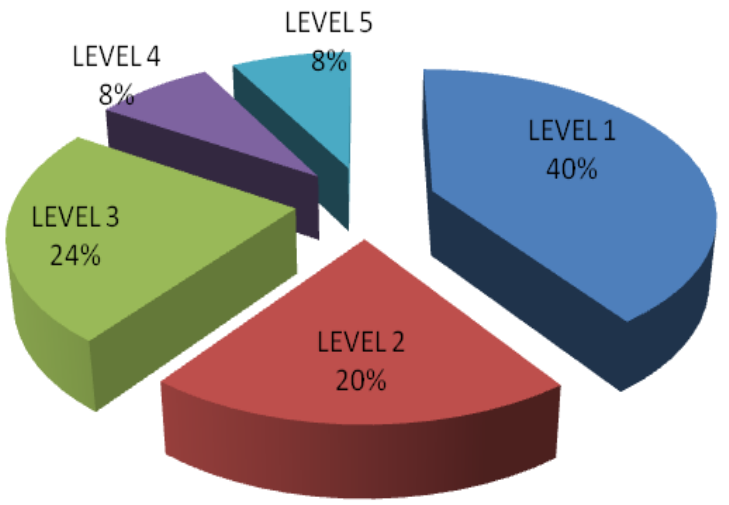

Fig. 4: Average pay in 2007

$\begin{aligned} & \text { Nigerian Universities Commission (NUC) } \\ & \text { requirements }\end{aligned}$
$\begin{aligned} & \text { staff overloading exists. The cost associated with the } \\ & \text { differences and the gap bridging policies are also } \\ & \text { shown in Table 13. The policy to adopt in bridging }\end{aligned}$
department under study with NUC requirement. It


Am. J. Sci. Ind. Res., 2012, 3(6): 345-357

TABLE 13: Comparison Between the Number of Staff on-ground and that of NUC norm in 2003.

\begin{tabular}{|c|c|c|c|c|c|c|}
\hline $\mathrm{S} / \mathrm{N}$ & GROUP & CATEGORY & $\begin{array}{l}\text { On- } \\
\text { Ground }\end{array}$ & $\begin{array}{l}\text { NUC } \\
\text { Norm }\end{array}$ & Difference & $\begin{array}{c}\% \text { age } \\
\text { difference(gap) }\end{array}$ \\
\hline \multirow[t]{3}{*}{1} & Academic Staff & i) Professor and Reader & 1 & 5 & 4 & $80 \%$ \\
\hline & & ii) Senior Lecturer & 1 & 9 & 8 & 89 \\
\hline & & iii) Lecturer 1 and below & 9 & 12 & 3 & 25 \\
\hline \multirow[t]{4}{*}{2} & \multirow{4}{*}{$\begin{array}{c}\text { Non-Academic } \\
\text { Staff }\end{array}$} & i) Senior Technical Staff & 1 & 7 & 6 & 86 \\
\hline & & $\begin{array}{l}\text { ii) Senior Administrative } \\
\text { Staff }\end{array}$ & 1 & 2 & 1 & 50 \\
\hline & & $\begin{array}{l}\text { iii) Junior Staff } \\
\text { a) Junior Technical Staff }\end{array}$ & - & 13 & 13 & 100 \\
\hline & & b) Junior non-technical staff & 4 & 18 & 14 & 78 \\
\hline
\end{tabular}

TABLE 14: Comparison Between the Number of Staff on-ground and that of NUC norm in 2007.

\begin{tabular}{|c|c|c|c|c|c|c|c|}
\hline \multirow[t]{2}{*}{$\mathrm{S} / \mathrm{N}$} & \multirow[t]{2}{*}{ GROUP } & \multirow[t]{2}{*}{ CATEGORY } & \multirow{2}{*}{$\begin{array}{c}\text { On- } \\
\text { Ground }\end{array}$} & \multirow{2}{*}{$\begin{array}{l}\text { NUC } \\
\text { Norm }\end{array}$} & \multicolumn{2}{|c|}{ Difference } & \multirow{2}{*}{$\begin{array}{c}\begin{array}{c}\% \text { age } \\
\text { improvement }\end{array} \\
2003 / 2007\end{array}$} \\
\hline & & & & & & $\%$ age & \\
\hline \multirow[t]{3}{*}{1} & $\begin{array}{l}\text { Academic } \\
\text { Staff }\end{array}$ & i) Professor and Reader & 2 & 5 & 3 & 60 & 20 \\
\hline & & ii) Senior Lecturer & 0 & 9 & 9 & 100 & -11 \\
\hline & & iii) Lecturer 1 and below & 9 & 12 & 3 & 25 & 0 \\
\hline \multirow[t]{4}{*}{2} & \multirow{4}{*}{$\begin{array}{c}\text { Non- } \\
\text { Academic } \\
\text { Staff }\end{array}$} & i) Senior Technical Staff & 1 & 7 & 6 & 86 & 0 \\
\hline & & $\begin{array}{l}\text { ii) Senior Administrative } \\
\text { Staff }\end{array}$ & 1 & 2 & 1 & 50 & 0 \\
\hline & & $\begin{array}{l}\text { iii) Junior Staff } \\
\text { a) Junior Technical Staff }\end{array}$ & - & 13 & 13 & 100 & 0 \\
\hline & & $\begin{array}{l}\text { b) Junior non-technical } \\
\text { staff }\end{array}$ & 3 & 18 & 15 & 83 & 5 \\
\hline
\end{tabular}

From Tables 13 and 14, between 2003 and 2007, the professorial grade recorded $20 \%$ improvement, the senior level worsened by $11 \%$. The Lecturer 1 level and below recorded zero growth, just as the senior technical and administrative staff. However, the junior non-technical carder recorded $5 \%$ improvement.

\section{CONCLUSION}

This study proposes an activity-based cost estimation model for estimating the manpower cost in the University System. The activities identified are formal teaching, practical, student assessment and consultation, formal examination, personal research, general administration and community services. Applying the model to industrial and production engineering education, it was observed that the cost 
per student in 100 level attracts $7.16 \%$ of the total cost, 200 attracts 26.37\%, 300 level and 400 level attract $36.98 \%$ and $13.53 \%$ respectively while 500 level attracts $15.96 \%$ of the total cost.

From the model developed, the estimated cost per student is dependent on the number of courses offered, the number and grade level of lecturers involved in the teaching as well as the number of students at each level. Therefore the estimated cost per student is not fixed. It could vary from department to department and from university to university depending on the factors already mentioned.

A comparison of the trend in 2003 and 2007 shows that the costs of borrowed courses are on the increase and should be closely monitored. For instance for the 100 level, between 2003 and 2007 it increased by $31 \%$.

While there is a general increase of between $15 \%$ and $20 \%$ in the cost it should be found out if this was real increase or due to inflationary pressures.

\section{RECOMMENDATIONS}

An examination of the cost heads shows that some areas of manpower requirements were not covered in this work. These include,

(1) Library, Clinics, Hostel, Registry, Accounts, General Administration and security. It is recommended that these should be investigated in further work.

(2) The industrial training programme is an important aspect of the training for the undergraduate courses. It involves supervision visits as well as grading and scoring of reports. Furthermore seminars are presented by students when they come back from the IT and these are also graded. All levels except 500 level are involved in IT programme. We recommend IT inclusion in further work.

(3) Departments and Faculties borrowing service courses from others should ensure that match the cost of such service courses.

(4) While emphasizing building on core competences, Faculty should not subsidize the inefficiency of the servicing departments.

(5) Activity based-models can also be developed for other cost heads in the university education, e.g. Equipment, Internet and other services.

(6) Finally, a generic computer program can be developed for the model developed in this work.

\section{REFERENCES}

Anyaeche, C. O. (2007), Funding of Higher Education in Nigeria, A Comparative Analysis of Federal, State and Private Universities: A Research Manuscript in the Department of Industrial and Production Engineering University of Ibadan.

Babalola J.B, Okunola P.O, Adeyemi. S. O. and M. E. lbekwe (1998) Costs and Financing of University Education in Africa. The Nigeria Experience. Study Programme on Higher Education Management in Africa. Revised Research report Number 4.

Babalola, J.B. (1994) The Economics of Access to Higher Education, UNESCO-AFRICA (Darka) Number 8 pp 714.

Babalola, J.B. (2001) University Funding, Responses and Performances Under a Declining Economy in Nigeria. Department of Educational Management, University of Ibadan, Ibadan, Nigeria.

Badran (2007) Enhancing Creativity and Innovation in Engineering Education European Journal of Engineering Education, Vol. 32, Issue 5 October 2007, pp $573-585$.

Craft, E. L. and Mack, L. G. (2001) Developing and Implementing an Integrated, Problem-Based Engineering Technology Curriculum in an American Technical College System, Community College Journal of Research and Practice, Vol. 25, Issue 5 and 6 June 2001, pp. 425 - 439

JAMB website http:// www.jambonline.org. accessed August 24, 2008.

JAMB brochure http://www.jambng.com accessed May 24, 2008

Talik, J. B. G. (2008)Transition from higher education as a public good to higher Education as a Private Good: the Saga of Indian Experience, Journal of Asian Public Policy, Vol. 1, Issue 2 July 2008 , pp 220 - 234

Rhonen-Yrjänheikki, K., Tukiainen, T. and Takala M., (2007) New challenging Approaches to Engineering Education: Enhancing University-Industry CoOperation: European Journal of Engineering Education, Vol. 32, Issue 2 May 2007 , pp 167 - 179. 
Kenneth, K. (1983) Forced Comparisons and Youden Square as a Basis of Improving Job Ranking in Job Evaluation. International Journal of Production Research, Vol. 21, No. 5.

Nilson, L., (1985) The University-Industry Interface in Swedish Engineering Education, European Journal of Engineering Education, Volume 10, Issue 2 1985, pp $155-158$

NUC website accessed July 30, 2007.

Ojelabi, A.O. and J.B. Babalola (1998) Effects of a Declining National Income on the Financial Modes of the University of Ibadan, Ibadan, Nigeria.

Partnership for Higher Education in Africa. 2002. Securing the Linchpin: ICT for Teaching,

Learning, and Research - a Workshop for African Universities. Addis Ababa.

Budhwar, P. S. and Boyne, G. (2004) Human Resource Management in the Indian Public and Private sectors: An Empirical Comparison, The International Journal of Human Resource Management, Vol. 15, Issue 2 March 2004, pp $346-370$.
Robert, W.G. (1982) Some Aspect of the Economics of University Activities. European Journal of Engineering Education, Vol. 7. No. 4

UNESCO, (1961). Manual on Adult and Youth Education. Paris: UNESCO. Location: Dallas SIL Library 808.3 N397.

UNESCO. 2003. Manual for Pilot Testing the Use of Indicators to Assess Impact of ICT Use in Education. http://www.unescobkk.org/education/ict/resource, accessed 21 August 2004.

William S. 1999. Tertiary Distance Education and Technology in Sub-Saharan Africa.

ADEA Working Group on Higher Education.

World Bank. 1999. Higher Education in Africa: Promoting Access, Quality and Capacity Building

in African Higher Education. Washington: ADEA Work Group, pp. 1-19. 